\title{
Porquê o Título de Especialista em Ginecologia e Obstetricia da FEBRASGO?
}

Desde a criação do Título de Especialista da FEBRASGO há trinta anos, ele passou a representar o aval da qualificação profissional perante a sociedade médica e, paulatinamente, passou a ser aceito entre os planos e órgãos promotores da saúde.

Neste período, o TEGO - FEBRASGO cresceu, modificando-se em prol do aprimoramento na metodologia da avaliação. Para nós, ginecologistas e obstetras, ele representa o certificado de qualidade e, como tal, deve ser valorizado. Devemos estimular que todos os ginecologista e obstetras obtenham o TEGO - FEBRASGO e premiar aqueles que o possuam, com convites para integrar comissões organizadoras de eventos e para participar ativamente de atividades científicas como mesas-redondas, palestras e conferências.

Importante também salientar que, com a integração dos serviços dos países que constituem o MERCOSUL, ele será o passaporte para o trabalho de ginecologistas e obstetras, à partir de 2001.

A Diretoria 